\title{
STAGES OF IMPLEMENTATION AND PROBLEMS OF IMPLEMENTATION OF INTERNATIONAL AUDITING STANDARDS IN UZBEKISTAN
}

\author{
Chairman of the board \\ Chambers of Auditors of Uzbekistan. \\ Dan. Karimov Nematullah
}

DOI: https://doi.org/10.31435/rsglobal_wos/31012020/6882

\author{
ARTICLE INFO \\ Received: 22 November 2019 \\ Accepted: 15 January 2020 \\ Published: 31 January 2020
}

\section{KEYWORDS}

international audit standards; problems of applying International Auditing Standards; prospects for the development of International Auditing Standards; advantages of applying International Auditing Standards; creation of specialized centers.

\begin{abstract}
This article is devoted to the study of the problems of applying international audit standards in the Republic of Uzbekistan. The author identified the main problems of applying international audit standards in the practice of audit organizations of the Republic of Uzbekistan, which include: insufficient qualified personnel, high costs of training or staff development, a language barrier, the complete absence of special domestic computer programs, the complexity of the content and structure of international audit standards. Along with the programs, the author presents the advantages of applying international audit standards, which include: providing a unified approach to auditing at the international level; trust is established by investors, creditors and shareholders; comparability of audit results between companies and countries is provided, and the competitiveness of audit organizations of Uzbekistan in the international arena is guaranteed; providing support from international institutions: the World Bank, the World Federation of Exchanges, the International Organization of Securities Commissions, the Committee on Financial Stability, etc. Development prospects are also proposed through the creation of specialized centers whose main functions are: professional translation of International Auditing Standards, publication of a special literature, training and exchange of knowledge and experience.
\end{abstract}

Citation: Karimov Nematullah. (2020) Stages of Implementation and Problems of Implementation of International Auditing Standards in Uzbekistan. International Academy Journal Web of Scholar. 1(43). doi: 10.31435/rsglobal_wos/31012020/6882

Copyright: (C) 2020 Karimov Nematullah. This is an open-access article distributed under the terms of the Creative Commons Attribution License (CC BY). The use, distribution or reproduction in other forums is permitted, provided the original author(s) or licensor are credited and that the original publication in this journal is cited, in accordance with accepted academic practice. No use, distribution or reproduction is permitted which does not comply with these terms.

The results of reforms in all sectors of the economy of Uzbekistan associated with the active integration of the Republic of Uzbekistan into the global economy also influenced the activities of audit organizations operating in the republic.

Over the years, a number of activities have been carried out by the authorized bodies in the republic aimed at implementing the International Standards on Auditing (ISA) - international professional standards for the implementation of audit activities. This is due to government policies aimed at liberalizing the economy as a whole .

The relevance of international standards is also due to the strengthening of global integration processes, which are accompanied, on the one hand, by the convergence of auditing standards, and on the other, by the desire of each country to protect national interests, including by strengthening the competitiveness of its enterprises in the world market.

It should be noted that according to the data of the compliance program conducted by IFAC in August 2012, even then, to some extent, ISA was applied by 126 countries.

There are 4 groups of countries according to the type of use of ISA: 
1. Countries that have enshrined in law the application of ISAs directly issued by IFAC. Among them: our neighbor - Armenia, Latvia, Estonia, Kazakhstan and Kyrgyzstan, Slovenia and other countries.

2. Countries that adopt the ISAs as local standards without any changes or additions. The difference between group 2 and group 1 is that if the IFAC publishes a new standard or changes the text of the standard, in group 1 it becomes mandatory for use immediately after its publication by IFAC. In group 2, the legislature should receive a translation of the standard into the local language and adopt the standard or amendment to it as a legislative act. Group 2 at the time of the study included 32 countries, incl. Great Britain, Czech Republic, Canada.

3. These are 29 countries (including Germany, Italy, France, etc.) that are developing their own standards based on ISA. The differences between local standards and ISAs are insignificant and comply with IFAC's policy on changes to standards.

4. Countries that develop national standards based on ISA, but there is no evidence that changes in local standards compared to ISA are consistent with IFAC policies. Among the 54 countries of this group are Russia, Ukraine, the USA and Japan. Russia, which is assigned to group 4, approved a bill in October 2013 that implies the introduction of ISAs as national standards, and since 2017 , instead of local audit standards, ISAs have been operating in Russia.

The application of international auditing standards, which have long been successfully used in many developed countries, is an important and necessary condition for Uzbekistan. The integration of the republic into the world economic community determines the basis for the development of audit as a full-fledged element of the market infrastructure, which, in turn, creates the need to improve the quality of audit services and the professionalism of auditors.

In this connection, the International Auditing Standards were first mentioned in the Decree of the President of the Republic of Uzbekistan dated November 26, 2010 PP-1438, according to which the audit organizations of Uzbekistan could apply international standards in their activities.

However, in practice, the transition to work in accordance with International Standards on Auditing in the republic was difficult. This was due to the fact that many business leaders did not understand the essence of classical audit, and were simply not interested in conducting it, the growing audit profession in Uzbekistan did not have work traditions in accordance with ethical standards generally accepted in developed countries, and work in accordance with international audit standards objectively complicated the audit process.

In this connection, at the initial stage there were certain coercive measures. In addition, it is extremely important that organizations are established that exercise control over which of the auditors already uses the International Standards on Auditing in their work, and which are not yet.

It should be noted that these coercive measures also positively influenced the activities of audit organizations.

As a result, a regulatory and methodological audit framework has been formed in the country that meets international requirements, which has allowed the creation of an audit services market and the entry of domestic audit organizations into large international networks of audit companies.

Also increased the growth of audit organizations included in the network of international organizations. For example, if the share of audit organizations included in various networks of international audit organizations in 2014 amounted to $14.4 \%$, then in 2018 it increased to $21.4 \%$ of the total number of audit organizations registered in Uzbekistan.

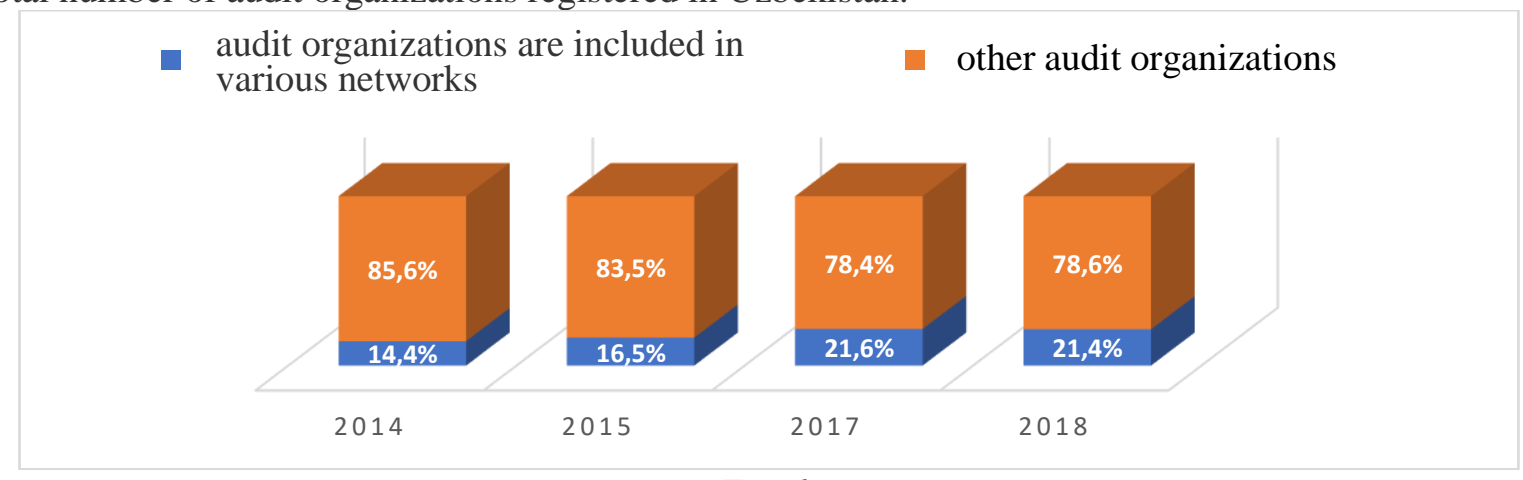

Fig. 1. 
Also in the subsequent September 19, 2018, the next Resolution of the President of the Republic of Uzbekistan was adopted regarding the further development of audit activities in the Republic, in which it was noted that audit organizations from January 1, 2020, they should carry out audit activities solely on the basis of international audit standards issued by the International Federation of Accountants.

Accordingly, questions about the applicability and status of the International Auditing Standards in Uzbekistan have also become relevant in terms of reforming the audit regulatory framework and a number of regulatory documents have been amended that regulate the procedure for conducting audit activities.

The need to introduce international audit standards in our country appeared due to the acceleration of the development of market relations, the formation of integration processes in the economy, the entry of individual audit organizations into large international groups, the introduction of international financial reporting standards.

At its core, the International Auditing Standards are documents that define the uniform requirements necessary to comply with and maintain an appropriate level of audit quality and related services. In other words, it helps to improve the quality of audit services and the professionalism of auditors.

In international audit practice, there are 4 main types of standards:

- General standards;

- Working standards;

- Reporting standards;

- Specific standards.

General standards determine who should conduct the audit, stipulate the need for independence, professionalism, and integrity.

General standards include the basic principles of auditing, the objectives and scope of an audit of financial statements, a standard on audit education, a letter of engagement from the auditor to the client.

The working standards contain requirements for planning inspections, monitoring the work of members of the audit team, studying the internal control system, sufficient justification for conclusions, and forming a convincing conclusion on their basis.

The working standards of auditing include planning audit work, audit evidence, the actions of auditors in identifying fraud or error, and quality control.

Reporting standards include the auditor's report on the audit of financial statements, types of audit reports, subsequent events after the balance sheet, after signing the audit report.

These standards require that the audit report contain comprehensive information about the nature of the audit and the degree of responsibility of the auditor.

Specific standards used for auditing in specific areas of activity include specific standards for auditing banks, insurance activities, etc.

The transition to international audit standards has the following positive aspects:

1) verification of the accuracy of financial statements taking into account the requirements of international auditing standards will contribute to the financial "transparency" of companies, and, as a result, may increase their investment activity in the international arena;

2) the use of international audit standards will increase the competitiveness of audit organizations and the ability to enter the global market for audit services, opening up opportunities for them to promote their services abroad;

3 ) in connection with the introduction of a unified approach to conducting audits in Uzbekistan and abroad, the procedure for assessing the activities of enterprises seeking to enter the international stock market is greatly simplified.

4) providing support from international institutions: the World Bank, the World Federation of Exchanges, the International Organization of Securities Commissions, the Committee on Financial Stability, etc.

As a result of the adoption of a number of resolutions aimed at preparing the financial statements of companies in accordance with International Financial Reporting Standards and the implementation of International Auditing Standards, the income of audit organizations has changed significantly. So, for example, the total revenue of audit organizations in 2013 amounted to 35.8 billion soums, and in 2018 amounted to 139.2 billion soums, or the growth compared to 2013 was 3.8 times. 


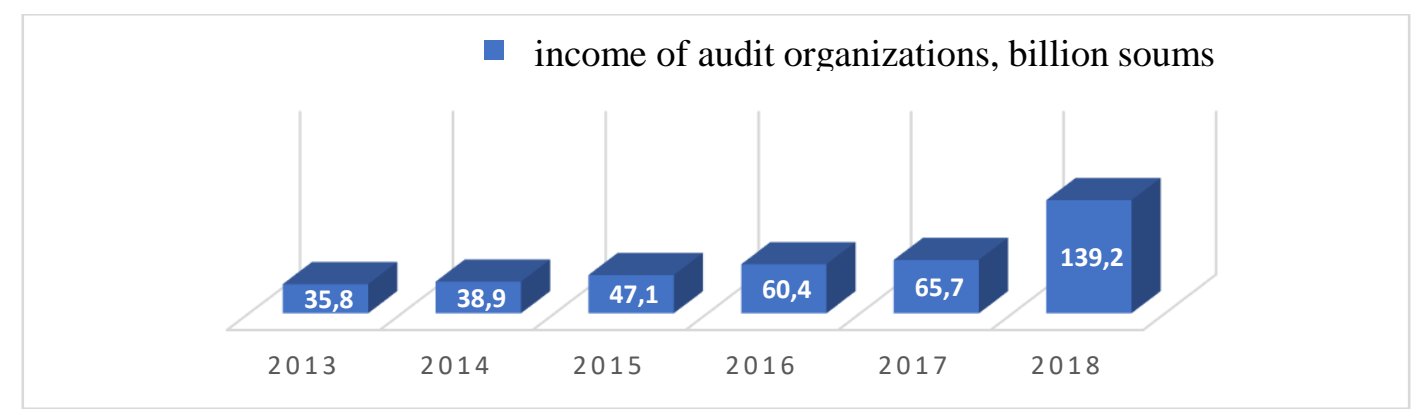

Fig. 2.

In essence, in order to form an unmistakable opinion on financial statements, the International Auditing Standards should ensure the proper quality of performance of duties on the part of auditors, as this document is the main document that controls and regulates audit activities.

At the same time, the transition to international standards will not only add to the work of the auditors, but also require a more versatile approach to the audit, i.e. take into account many aspects of the work of the audited company, identify all kinds of risks for the business, and draw up more detailed information about the audit work done.

Issues of application and transition to International Auditing Standards are also considered in the Russian Federation. However, according to the candidate of economic sciences M. E. Vasilenko, assistant professor of accounting and auditing at the Institute of International Business and Economics of the Vladivostok State University of Economics and Service, many more tasks still have to be done to increase the competitiveness of domestic auditing. One of them is the standardization of audit activities.

In the opinion of M. E. Vasilensky, despite the fact that the International Audit Standards can significantly affect the development of auditing in accordance with international requirements, the Russian Federation independently develops audit rules (standards).

However, some experts believe that the level of economic development of the Russian Federation makes it inappropriate to use the International Auditing Standards in Russia.

In their opinion, the Russian audit standards are an adapted system of international audit standards. Russian standards differ from the International Auditing Standards in terms of structure, presentation logic, they contain application examples for Russian application practice. Since 2010, the differences also include changes to the International Auditing Standards in accordance with the implementation of the Clarity project. The aim of the project is to increase the clarity of standards and ensure a uniform understanding of their requirements in different jurisdictions. The result was a change in the structure and nature of the presentation of standards. Currently, the official translation into Russian of the latest edition of the International Standards on Auditing is the 2017 version of the publication.

Foreign and domestic scientists have been studying the problem of transforming international audit standards into Russian practice for quite some time.

In our opinion, the application of international auditing standards, which have long and successfully been used in many developed countries, is an important and necessary condition for Russia. Due to the fact that the integration of Russia into the world economic community determines the basis for the development of audit as a full-fledged element of the market infrastructure, the introduction of International Auditing Standards would be a necessity in improving the quality of audit services and the professionalism of auditors.

The audit firms of the Big Four conduct audit activities in accordance with the requirements of international audit standards. Their universality, among other things, lies in the fact that they are applicable regardless of how the audit is conducted, whether it is an independent audit of the financial statements of a profitable or loss-making enterprise. The specifics of the organization, its legal status, and the scope of activity do not matter.

Therefore, all these changes will ultimately lead to an increase in the cost of audit services, as well as contribute to increasing the competitiveness of audit companies.

It should be noted that with the beginning of these reforms, some other difficulties may also arise in the process of integration into the global community of auditors, including: organizations.

1) the organization of control over the implementation of international standards by audit 
2) the introduction of new audit requirements will lead to an increase in the amount of data needed to analyze the activities of audited organizations. In this regard, there will be an increase in the complexity of the audit, and, consequently, its cost;

3) audit organizations must bring internal audit standards into line with international requirements, which requires a certain amount of time.

4) the occurrence of erroneous confidence that the activities comply with all international standards due to a lack of understanding by auditors of the principles of international standards.

Also, during the analysis of the composition of the existing National Auditing Standards of the Republic of Uzbekistan and the adopted International Auditing Standards, it was found that a number of national standards had similar provisions in content to international standards.

In a formal comparison of the two standards, it was found that the National Auditing Standards were more concise and framework, while international standards contain clearer, more detailed instructions describing a large number of subtleties and contentious issues. Owls arising during the audit.

Also a distinctive feature of international standards is an integrated approach to their development. The provisions of each standard are closely interconnected with the provisions of other standards in the system of International Auditing Standards.

Another important factor that should be considered when introducing international standards in Uzbekistan is the task of ensuring the accuracy of the translation and, accordingly, the correctness of the terminology. For example, currently in Uzbekistan there is an official translation of the International Auditing Standards approved in 2013.

These International Standards on Auditing contain principles, methods, procedures for conducting audits, as well as relevant recommendations in the form of explanatory and other material to ensure their application. In content, the structure of all standards, regardless of belonging to a particular group, is built on the same principles and principles and includes the following sections:

- Introduction, where the purpose and objectives of the standard are formulated and the terminology used in the standard is considered;

- the main content, including paragraphs, which sets out the provisions of this standard;

- applications where recommendations for practical application are given in the form of a list of factors, causes, samples, schemes, tables, etc.

The international audit standards of 2013 included 36 standards and 1 international quality standard.

A significant change relates to the form and content of the audit report. If earlier the auditors processed a significant amount of information, but issued only a brief conclusion, then after the entry into force of international standards in Uzbekistan, instead of a single page with standard text, a more extended and information-rich assessment of the financial statements of the organization is proposed. The new form of the audit report not only evaluates the financial statements of enterprises, but also draws attention to the most important points in the activities of the audited entity, including what attracted the greatest attention of the auditor, what the auditor sees the most significant risks to the business, etc. P.

Thus, the new form of the audit report presupposes expanded information not only for accounting, but also for external and internal interested users: shareholders, the board of directors, etc., that is, a wider circle of people who make decisions about the business development strategy.

Undoubtedly, the disclosure of additional data in the audit report will allow investors and counterparties of companies to make more informed business decisions. However, as a result, one should expect not only an increase in quality in assessing business risks, but also an increase in the cost of auditing. In addition, financial risks increase, since increasing the level of transparency of the company and reflecting all identified business risks in the audit report will automatically lead to more expensive bank loans for companies.

In general, in order for the introduction of International Auditing Standards in Uzbekistan to be successful, the following conditions must be met:

1) ensure the unification of the terminology used in international auditing standards, which will minimize the risk of incorrect understanding of the key provisions of the International Auditing Standards;

2) carry out the development by the authorized body of methodological materials explaining the application of certain provisions of the International Auditing Standards;

3) bringing audit organizations in-house standards in accordance with the requirements of international standards;

4) conduct systematic monitoring of changes to the original International Auditing Standards; 
5) provide control over the implementation of International Auditing Standards and public organizations of auditors.

Nevertheless, it can be concluded that international auditing standards are simply necessary. To understand the position of the company and the results of its economic activities, an objective document is needed, and such is the financial statements.

Third-party investors are interested in making sure that it is reliable. Therefore, the audit is carried out using the same procedures as in the West, which, by all rules, are understandable to foreign investors. In addition, investors should also be interested in ensuring that the information they are interested in is reliable and that the audit is conducted in good faith.

Due to the tightening of the requirements for the organization of an accounting and reporting system, which are the main source of information for assessing the financial condition of business entities, the quality of the audit of financial statements has improved, which generally affected the quality of financial information. The users of financial statements are interested in the auditor's report, which should provide complete information about the financial situation and financial results, they are also interested in the qualification, competence and objectivity of the auditor.

Increasing financial "transparency" of companies and, as a result, attracting Foreign investors are associated with the use of understandable and internationally accepted standards for auditing. It also paves the way for international audit due to competition in the world arena, as the position of Russian auditors in competition is strengthened by focusing on International Auditing Standards.

Thus, international standards should become an effective tool in improving the quality of auditing and introducing a new integrated approach to the formation of financial information.

In our opinion, several organizations should be involved in the process of implementing International Auditing Standards in Uzbekistan. Moreover, this process should be coordinated both by professional organizations and by authorized state bodies.

In our opinion, the quality of audit services in Uzbekistan largely depends on the training of auditors. Training of future auditors is carried out in universities of Uzbekistan. Most auditors have a basic education in the specialty "Accounting, Analysis and Audit".

However, at present, the transition to a two-tier system of higher education (undergraduate graduate) has led to a new problem: on the one hand, this is a restructuring of the educational process, which allows to increase the efficiency of using budget funds; the opportunity to receive a two-in-one higher education: to complete a bachelor's degree in one direction, and to get a master's degree in another way, and also provides an opportunity for students to continue their studies in any European university, but on the other hand, this transition negatively affects the knowledge and skills of university graduates .

The fact is that the training program for future auditors in the direction of undergraduate "Accounting, Analysis and Audit", involves a shortened study period of 4 years, that is, less time is 3.5 times than specialists studying according to the 2000 standard.

The result of this may be: - the labor market is not ready to consider bachelors as people with completed higher education, and if diplomas of Uzbek universities are recognized in the West, this will lead to a "brain drain"; - A bachelor's diploma is recognized as a diploma of higher education, but employers are skeptical of them and want to see full-time specialists in their staff; - the lack of professional knowledge obtained in undergraduate studies will affect the quality of the services provided. - insufficient level of knowledge obtained by the auditor in the learning process, leads to problems passing the qualification exam.

To solve the problems, it is necessary first of all to improve the professional training of personnel.

To this end, the Chamber of Auditors of Uzbekistan, together with the Ministry of Finance of the Republic of Uzbekistan, is actively working on cooperation with the Association of Certified Public Accountants.

The possibilities of wider use of modern technologies in the educational process are evaluated; Possibilities are provided for the active involvement of practicing specialists in the training process; It is planned to practice foreign internships for the future auditor;

In the educational process, use the conduct of courses, trainings, seminars aimed at improving the knowledge of auditors. 


\section{REFERENCES}

1. Decree of the President of the Republic of Uzbekistan dated November 26, 2010 N PP-1438 On priority directions for further reforming and increasing the stability of the financial and banking system of the republic in 2011-2015 and achieving high international rating indicators.

2. Decree of the President of the Republic of Uzbekistan dated April 24, 2015 No. UP-4720 "On measures to introduce modern methods of corporate governance in joint-stock companies" noted,

3. Decree of the President of the Republic of Uzbekistan dated September 19, 2018 No. PP-3946, "On measures for the further development of audit activities in the Republic of Uzbekistan".

4. Isakova S. A. Current problems of audit organization in the transition to international audit standards // Economic analysis: theory and practice. 2009. No. 30.

5. Merzlikina, E. M. Nikolskaya, Yu. P. Audit: textbook. allowance / E. M. Merzlikina. - M.: INFRA-M Publishing House, 2009. - S. 367.

6. Shvets O.V., Mikhalischeva P.S. The main directions of reforming the regulatory framework of auditing in Russia through the transition to international auditing standards // I interuniversity scientific-practical conference "Actual problems of economics and management". - 2017. - S. 26-30.

7. Crow T.M., Oleinik M.A. Transition to international audit standards in Russia // Collection of articles on the materials of the VIII All-Russian Scientific and Practical Conference of Young Scientists "Problems and Prospects for the Development of Economic Control and Auditing in Russia". - 2017. - S. 10-15.

8. Skrypnik D.D., Makaryeva V.Yu. Problems and the need to apply international audit standards in Russia // Modern research and development. - 2018. - No. 1 (18). - S. 365-367.

9. International auditing standards. http://www.ifac.org/publications-resources/2016-2017

10. Temirkhanova M. Zh. Ways to improve the accounting for liabilities in the travel agency // European Journal of Economics and management Sciences. 2017. No. 2. P. 3-6.

11. Temirkhanova M. Zh. Regulatory framework for the organization of financial accounting and reporting in tourist organizations of the Republic of Uzbekistan // Herald of science and education. 2016. No3. S. 18.

12. Temirkhanova M.Zh. Analysis of financial results tourism organization. International Scientific and Practical Conference World science. 2016. T. 4. № 9 (13). C. 16-19.

13. Temirkhanova M.Zh. Improving reporting forms according to international standards Bulletin of science and practice. 2017. No. 11 (24). S. 317-326. 